\title{
\begin{tabular}{|l} 
International Journal of Educational Spectrum \\
\hline educational spectrum
\end{tabular}$\quad$ Uluslararası Eğitim Spektrumu Dergisi
}

\section{Georgia in the Context of the European Educational Area}

\author{
Avrupa Eğitim Alanı Bağlamında Gürcistan \\ Manana DARCHASHVILI' ${ }^{1}$ \\ Article History: $\quad$ Received: 29.12.2020 / Accepted: 03.01.2021 \\ Makale Geçmişi: Geliş: 29.12.2020 / Kabul: 29.01.2021
}

Doi: https://doi.org/10.47806/ijesacademic.849760

\begin{abstract}
In Georgia, the issue of education has always been a priority for the government of all times, with a focus on further development. In 2005, when Georgia joined the Bologna Process, significant reforms were made in the higher education system. Higher education programs are described in the European Credit Transfer System. Accordingly, the diploma supplement is approved following the rules developed in Europe. The paper examines the compatibility of the country's education system with the law, according to which the existing higher education institutions must comply with both internal and external quality assurance mechanisms. The external quality assurance system of Georgia consists of authorization and program accreditation, and external quality assurance is provided by LEPL National Center for Education Quality Development. The paper presents the ways and means of Georgia's firm establishment in the European educational space and the contribution of the National Center for Quality Development in Education so that the quality of education received in Georgia fully meets national and international requirements.
\end{abstract}

Key Words: Georgia, education, Europe, programs, involvement.

\section{Özet}

Gürcistan'da eğitim meselesine hükümet tarafından daha fazla gelişime odaklanılarak her zaman öncelik verilmiştir. 2005 y1lında Gürcistan Bolonya Sürecine girdiğinde, yüksek öğretim sisteminde önemli reformlar yapılmıştır. Yükseköğretim programları Avrupa Kredi Transfer Sisteminde tanımlanmıştır. Buna göre, diploma belgesi, Avrupa'da geliştirilen kurallara göre onaylanmaktadır. Bu çalışma, ülkenin eğitim sisteminin, mevcut yükseköğretim kurumlarının hem iç hem de dış kalite güvence mekanizmalarına uyması gereken prensiplerle uyumunu incelemektedir. Gürcistan'ın dış kalite güvence sistemi, yetkilendirme ve program akreditasyonundan oluşur ve diş kalite güvencesi Ulusal Eğitim Kalite Geliştirme Merkezi tarafından sağlanır. Aynı zamanda bu çalışma Gürcistan'da alınan eğitim kalitesinin ulusal ve uluslararası gereksinimleri tam olarak karşılaması için Avrupa eğitim alanında Gürcistan'ın sağlam yapısını sağlayan yolları ve araçları ve Eğitimde Kalite Geliştirme Ulusal Merkezi'nin bu bağlamda katkısını irdelemektedir.

Anahtar Kelimeler: Gürcistan, eğitim, avrupa, programlar, katılım 


\section{Introduction}

The issue of education in Georgia is actively discussed in the agenda of political life after the restoration of state independence and became an important area of common interest. Therefore, taking care of education issues represents one of the important priorities for the government of the country. The current situation is the following - Georgia is involved in the European Neighborhood Policy, which represents a significant challenge in the country's foreign policy. Consequently, coherence with the European Union Education Area on several issues is also interesting, topical, and at the same time important for cooperation. Due to this, Georgia started working in this direction as soon as it adopted an independent action plan.

The paper examines the EU-Georgia cooperation in the field of education in the context of the current reality of higher education. In this regards the effective steps have been made by the state to coordinate with the issue of European cooperation in the field of education, which is a decisive factor for the development and strengthening of a stable, peaceful democratic society. The study shows that Georgia's current policy is aimed at improving and developing its cooperation with the European Union, thus the government has worked out certain effective mechanisms in various directions following the EU action plans.

Particularly, the government has done its bests to harmonize the issues of Georgia-EU education, and in this regard, the participation of European colleagues in the monitoring and implementation of the Georgian policy action plan based on recent experience and current trends in the world is crucial. At the same time, we have to refer to the opinion of the Georgian society, which thinks that education and educational cooperation with Europe, will improve the state's stability and lead to the peaceful sphere, guaranteeing the advancement of democracy.

\section{Review of Literature}

In Georgian realities, it is very important to study the problems related to education, and understand the results of the conducted reforms, hence great attention is paid to the correspondence of trends and the existing priorities in the world. On this occasion, a lot of studies have been conducted, however, the paper will review only a few of them.

Tamar Bregvadze's paper "Strategic Development of Higher Education and Science in Georgia" deals with the issue of higher education and employment, where the analysis of higher education policy is discussed in terms of five strategic directions. To fully understand the problem and consider it in the future, in order to increase the compatibility with the requirements of the higher education market the authors explain certain examples of best practices and discuss them on the example of developed European countries (Bregvadze, 2013).

Despite the positive results of the conducted reforms in the education sphere, the Georgian education system still could not manage to train graduates so that they meet the requirements of the labor market. The mentioned issue is related to the work of E. Bochorishvili and N. Peranidze, "Education Sector in Georgia" (2020), which discusses the main trends, challenges, and opportunities in the education sector. The study presents a detailed analysis of the education sub-sectors (including higher education which is a subject of our interest) along 
with a general overview of the education industry, as well as the labor market and the economic benefits of education for graduates (Bochorishvili, Peranidze, 2020).

Situational analysis of the education system of Georgia is presented in I. Gurgenashvili's work "Georgian Education System" published in 2018, which is based on secondary data processing, presents a situational analysis of 2012-2018 in various areas of important components of the education system. Moreover, it discusses the Georgian education system in international rankings and the budget of the Ministry of Education (Gurgenashvili, 2018).

\section{Methodology}

The paper is based on a qualitative method of research and on several collected empirical materials, various government documents, papers, analysis of primary sources posted on official websites, using the method of historicism.

\section{Results and Discussion}

\subsection{Georgia in the European Educational Space}

Georgia, as a country aspiring to European integration, is considered a part of Europe geographically and in terms of history, culture, and traditions, where the society together with the government realizes the transformation of the country into the European model and is aware of the required obligations for cooperation (Malazonia, Maglakelidze, Chiabrishvili, 2017).

Relations between Georgia and the EU have been positive from the very beginning of cooperation, in 1999 the Partnership and Cooperation Agreement between Georgia and the EU entered into force, which also covers cooperation on various issues, and since 2004 relations have acquired qualitatively new perspectives after the adoption of the European Neighborhood Policy. Under the European Neighborhood Policy, the EU offers its member states development cooperation. In parallel with these processes, the agenda actively discusses many legislative changes, which address all the important challenges on the agenda of education systems in developed European countries to form a European-level education system in the country.

Cooperation in the field of education is facilitated by various European Union programs such as Tempus, Erasmus Mundus, etc., which are aimed to introduce European standards in the EU partner countries, develop modern curricula, improve qualifications, use and develop new information technologies. The European Union's Tempus program was established in 1990 (Tempus and Erasmus Mundus in Georgia, 2014), and Georgia has been participating in the program since 1995, which to some extent contributed to the implementation of the Bologna Principles. Georgia was one of the best EU partner countries in terms of the number of participating universities. Many important steps have been taken within the framework of the project, and the results achieved have increased the interest and motivation of Georgian universities to participate in international programs.

Georgia has been a member of the European Higher Education Area (EHEA) since Bergen Summit, 2005. Consequently, it has the opportunity to cooperate internationally in the sphere of the higher education system with countries of deep cultural and academic traditions which, 
for decades, have gradually developed several commitments on higher education based on common core values, such as freedom of expression, the autonomy of institutions, independent student associations, academic freedom and free mobility of students and staff. Through this process, European countries, institutions, and stakeholders are constantly adapting their higher education systems to the modern requirements of common interests, making each of them more compatible in a common system and strengthening quality assurance mechanisms. The main goal for all of these countries is to increase staff and student mobility and promote employment.

Following the signing of the Bologna Declaration, the universities of Georgia are implementing the basic principles of the Bologna Process. At the same time, there is an important condition for integration into the European educational space - lifelong learning, lifelong education, which is a priority for Georgian universities.

In the context of Georgia's active involvement in the Bologna Process, the government has been striving to take effective steps towards full integration with the European Union since its accession. Particularly, significant changes have been made to the higher education system in terms of compliance with quality assurance standards at the European level; diplomas issued in Georgia are recognized in many European countries (integration of Georgian specialists into Europe); the mobility of students and scientists from Georgia to world universities is implemented through various programs; as well as promoting the formation of Georgian and world cultural values with an emphasis on the ideas of democracy and humanism, which are necessary for international cooperation and development. However, well-reasoned critical approaches to this issue should be noted, in particular, such as a three-stage learning model, the formal characteristic features of the involved local teachers and students, the advantages of studying abroad, etc. (Khizanishvili, Akhaladze, 2015).

For the Georgian reality, the Eastern Partnership initiative launched in 2009 is very important, because the goal of this new political initiative for the country was to strengthen the European Union and the Eastern Neighborhood. Public support within the Georgia-EU bilateral format is high, which is further publicized by the Georgian government, based on the European Neighborhood Policy. Here we have to say that the "EU's supervision on the Georgian reforms" has turned into a real mutually beneficial cooperation (Gogolashvili, 2013).

Since 2009, the Erasmus Mundus Joint Program has been run by consortia of universities in European and Partner countries. Over the years, many students from Georgia have benefited from this program for masters and doctoral studies (Tempus and Erasmus Mundus in Georgia, 2014). It should be noted that the merit of the work of the group of experts on the ground is to establish a place in the European educational space. It was under their leadership that they regularly participated in local and international events and developed recommendations (Bakradze, 2020).

The Georgia-EU Association Agreement was signed on June 27, 2014. Among the other important issues related to the essence of the agreement, there are such issues as "Modernization of all areas of sectoral policy and the introduction of European standards", the issue of education was also considered here. Besides, this Agreement provides further 
deepening of cooperation between Georgia and the European Union in all priority areas, including education, which will help to improve the quality of education and, lead to the legislative harmonization, the creation of a unified framework of qualifications and competencies, and education and the introducing the European scoring system (Center for Development and Democracy, 2016).

According to the agreement, Georgia's rapprochement with EU education and science policy and practice pays special attention to higher education and brings it in line with the EU's Higher Education Modernization Agenda, which aims to increase graduation rates, improve quality and improve mobile quality. Promoting international cooperation, partnerships between research and business, including the use of research results, innovation by universities, the development of entrepreneurial, innovative skills, governance, funding improvement (National Center for Education Quality Development, 2019.

All of this in turn envisages collaboration in the following areas - lifelong learning, which is a good opportunity for career growth, modernization of the education system, growth of quality, compliance, and accessibility at all levels of education.

After Georgia acceded to the EU International Organization for Research and Innovation in 2019, to facilitate Georgia's integration into the EU scientific research area there was established "EURAXESS Georgia", which gives universities and research institutes ample opportunity to expand international cooperation (Shota Rustaveli National Science Foundation of Georgia, 2019).

Following the requirements of the European Higher Education Area in Georgia, the agenda of the Association Agreement between Georgia and the EU, some important measures have been taken in the quality assurance system of higher education, aimed at compliance with external standards at national and international level (Erasmus + Georgian National Office (National Center for Education Quality Development, 2019).

The various universities of Georgia within the framework of Erasmus + must cooperate in several scientific research projects, in the field of education (science, technical, civic education, and promotion of democracy) with universities in Europe, which is a unique opportunity for development.

Here we have to mention the international cooperation within the framework of the "Horizon-2020" program as it has a special significance for the Georgian reality. Specifically, we have to highlight the Georgian project - "Science is a Captain", presented by the Ministry of Education, Science, Culture and Sports of Georgia and the Shota Rustaveli Georgian National Science Foundation to the Maria Sklodowska-Curie Competition (MSCA), about the "Night of European Researchers", which is a European Framework Program for Research and Innovation "Horizon 2020" (Ministry of Education, Science, Culture and Sports of Georgia, 2020). Due to the events held remotely in such big cities of Georgia as Tbilisi, Telavi, Kutaisi, Batumi, Akhaltsikhe, Zugdidi within the framework of the project, Georgia for the first time (November 27-28, 2020) will participate in the current festival together with the EU countries (total number of participants is 30 countries). 
The Georgian reality is the center of attention (with great prospects) for the development of education and science in the Eastern European region. In this regard, we have to highlight one of the important contributing factors is Kutaisi International University. Which, within the framework of the project "Learn in Georgia", has more prospects for activating international programs in foreign languages, as well as promoting the international cooperation between students and scientists.

A key aspect of the co-operation is the establishment of the first Eastern Partnership European School of regional importance outside the EU at the initiative of the European Union and in agreement with the Government of Georgia. This is a very important fact for the country, which represents the 20th goal of the "20 key goals for 2020" developed by the European Union (Abuladze, 2019).

\subsection{Georgian National Center for Educational Quality Enhancement and the European Union}

One of the important visions of the National Center for Quality Development in Education is to get closer to the European educational space. Accordingly, its activity is to ensure the compliance of the National Qualifications Framework with the European one. Just a few months ago, the center became a member of the Central and Eastern European Higher Education Quality Assurance Agency (CEENQA) network, which allows it to actively collaborate and be engaged in discussions on European Higher Education Quality Assurance Policy, liaising with member agencies, sharing experiences and important internationalization opportunities.

When discussing Georgia-Europe education, it is necessary to mention some important details of cooperation, in particular, the relationship between the European University Association (EUA), the National Center for Education Quality Development, and the fact that 5 universities from the Georgian educational space are its members (1. Georgian Technical University, 2. Ivane Javakhishvili Tbilisi State University 3. Ilia State University, 4. Tbilisi State Medical University, and 5. Davit Tvildiani Medical University). Membership in this organization is a certain responsibility for Georgian universities to ensure quality improvement. The cooperation with the Association allows them to participate in several European educational projects, in the formation of future EU higher education policies and initiatives. It should also be noted that this center is the first quality assurance agency in Europe to receive recognition from the World Federation for Medical Education (WFME), with the requirements of the World Federation of Medical Education (National Center for Quality Development in Education, 2018). Their recognition means worldwide recognition and the unique opportunity for the medical graduates of Georgian universities to be employed and continue their studies in any European country.

The National Center for Education Quality cooperates with several European foundations and associations, a number of projects have been implemented (National Center for Education Quality Development). In this regards, we can mention the fact that in 2010, in coordination with the Center, the project "Promoting the Comparison of Quality Assurance in Internationalization and Higher Education" was launched within the framework of the European Union "Tempus" program, which aimed to develop a quality assurance model in 
Georgia and Armenia and bring them closer to EU standards (2010-2014). Together with Georgia and Armenia, Germany was also involved in this three-year project as a coordinating country, as for the partner countries, they were France, Spain, and the Netherlands.

Since 2012, the Center has been involved in the Tempus program again, in the project development program of Georgia and Armenia, Master of Education Management (until 2015), together with the Center from Georgia, the Ministry of Education and Science of Georgia and universities (5 universities).

From 2014 to 2017, the Center was involved in a project under the same program, which aimed to modernize mathematics curricula in the universities of the South Caucasus, engineering, and natural sciences, using modern teaching technologies. The members of the were higher education institutions from Georgia, Armenia, France, Germany, and Finland. The Georgian side was represented by the National Center for Education Quality, the Georgian Scientific-Educational Computer Networks Association, the Georgian Technical University, Batumi Shota Rustaveli State University, Akaki Tsereteli State University, and the University of Georgia.

In 2015-2017, the National Center for Education Quality was involved in the Tempus program - "Promoting the quality and recognition of transnational education in Armenia and Georgia", which aimed to develop internal and external mechanisms for ensuring the quality of transnational education, coordinated by partners and participants from different countries. Cooperation with the European Education Foundation (ETF) which started in 2017 is very important, as has funded a package of legislative changes and an action plan for the implementation of the updated National Qualifications Framework which has been prepared by local and international experts to align the qualifications framework.

Since 2019, the National Center for Education Quality has become a full member of the European Association for Quality Assurance in Higher Education (ENQA) (for a period of five years). According to which were established several vital projects such as The Compatibility of the National Higher Education Quality Development System with the quality assurance standards and guidelines of the European Higher Education Area; were fulfilled the obligations under the Georgia-EU Association Agreement, which ensures a high level of reliability towards the evaluation systems of higher education institutions and educational programs; strengthens international partnerships and internationalizing higher education (National Center for Education Quality Development, 2019).

The aim of the current project (implemented since October 2019) - "Strengthening Quality Assurance and Qualifications Management Capacities" is to promote human capital development through quality assurance, transparency, skills, and qualifications management for "lifelong learning". The project has three components: 1. To strengthen the provision of quality education and training concerning "lifelong learning"; 2. Participate in the introduction of a new framework of national qualifications; 3. Facilitate the improvement of the management, monitoring, and dissemination model of the results of the activities of the National Center for Education Quality Development. The project is implemented by Germany and Estonia, the partners are the German Academic Exchange Service (DAAD) and the Estonian Agency for Quality Assurance in Higher and Vocational Education (EKKA), the 
project is funded by the European Union (Ministry of Education, Science, Culture, and Sports of Georgia, 2020).

The National Center for Quality Development in Higher Education of Georgia continues to promote the implementation of the goals and principles of the European Higher Education Area not only in theory but in practice as well. In this regards, the Center became a partner of the project for Assessment Tool and Incentive Systems for Developing Higher Education Teachers' Performance called Performance, which aims to support educational institutions in the European Higher Education Area and to improve the quality of teaching and learning, encouraging and promoting academic staff for professional development, incentives (Ministry of Education, Science, Culture, and Sports of Georgia 2019).

At the present stage, when the Covid 19 pandemic has brought the higher education system to a new level, the issue has to be solved in the both European and the Georgian educational space. In particular, due to the pandemic in Georgia, higher education institutions were faced with a serious challenge, therefore, in order to create a legal basis for a new form of education, appropriate changes were made in the law on education. I think it was very vital for Georgia, as a member of the European University Association (EUA) and the European Association for Quality Assurance in Higher Education (ENQA) to share their experience (universities have overcome difficulties) and Georgian experts constantly give us detailed information about the European experience (Bakradze, 2020). Research confirms their interest in the detailed study of the issue, even at the level of terminology. It is a fact that that the survey conducted by the EUA in 2014 is similar to the content of the 2020 survey and the form of implementation of the study does not matter (EHEA, 2020).

\section{Conclusion}

A number of empirical materials discussed in the paper on aspects of Georgia-EU education coherence show that the Georgian government has made systemic changes in the field of education over the years to provide a solid foundation for the country's democratic, economic and social development to gain the regional leadership and become a regional educational center. For this, it implements certain large-scale projects to attract students to Georgian higher education institutions.

The Bologna Process, despite its heterogeneous attitude towards the issue in the country, has had a positive impact on education policy in Georgia in terms of quality assurance.

The National Center for Education Quality Development, through various projects, continues to promote the implementation of the goals and principles of the European Higher Education Area in the field of higher education in Georgia not only in the theory but as well as in practice.

Through new approaches, support, and programs, the country's youngsters and scholars have gained a unique opportunity to internationalize Georgian education and share international experiences.

With the support of the state, several important projects are being implemented, within the framework of which the pace of international cooperation is increasing. 


\section{References}

Abuladze, I. (2019). About the Eastern Partnership European School. Ministry of Education, Science, Culture, and Sport of Georgia. Retreived on the $10^{\text {th }}$ of September, 2020 from https://mes.gov.ge/content.php?id=9452\&lang=eng

Bakradze, L. (2020). New Educational Reality. Tbilisi: Erasmus + Georgian National Office.

Bakradze. L. (2020). A New Educational Reality Glossary, Challenges, Recommendations. Tbilisi: Higher Education Reforms Experts.

Bochorishvili, E., Peranizde, N. (2020). Education Sector in Georgia. Tbilisi: GALT \& TAGGART Research.

Bregadze, T. (2013). Strategic Development of Higher Education and Science in Georgia. Tbilisi: International Institute for Education Policy, Planning, and Management.

Center for Development and Democracy (CDD). (2016). Tbilisi: Georgia and the European Union in the Footsteps of Development and Reform. Retreived on the $10^{\text {th }}$ of September, 2020 from http://cdd.ge/en

European Commission. (n. d.). Bologna Process, European Higher Education Area, and Bologna Process. Retrieved on the $5^{\text {th }}$ of September, 2020 from https://ec.europa.eu/education/policies/higher-education/bologna-process-andeuropean-higher-education-area_en seen

Erasmus+ Georgian National Office. (2019). (NEO). Submission of Analysis of the Introduction of Updated Authorization Mechanisms. Retrieved on the $13^{\text {th }}$ of October, 2020 from https://erasmusplus.org.ge/ka/news/eqe-conference

European Higher Education Area and Bologna Process (EHEA). (2020). Survey on digitally enhanced learning in European higher education institutions. Retrieved on the $10^{\text {th }}$ of October, 2020 from https://www.eua.eu/downloads/content/survey.pdf

Gogolashvili, K. (2013). What does the Eastern Partnership promise us? Tbilisi: Georgian Foundation for Strategic and International Studies.

Gurgenashvili, I. (2018). Georgian Education System. Tbilisi: Georgia's Reforms Associates.

Khizanishvili, M., Akhaladze, T., (2015). The Bologna Process and Critique of the Bologna System. Retrieved on the $10^{\text {th }}$ of September, 2020 from http://intermedia.ge

Malazonia, D., Maglakelidze, Sh., Chiabrishvili, N., Gakheladze, G. (2017). Intercultural Education: Problems, Their Analysis, and Development Perspectives in Georgia. Tbilisi: Ilia State University.

Ministry of Education, Science, Culture, and Sports of Georgia. ( 2020). The winning project of the European Competition "European Researchers' Night" "Science Captain" is launched. Retrieved on the $5^{\text {th }}$ of November, 2020 from https://www.mes.gov.ge/content.php?id=11378\&lang=geo

Ministry of Education, Science, Culture, and Sports of Georgia. ( 2020). Public Service Twinning Project about Strengthening Quality Assurance and Qualifications Management Capacities. Retrieved on the $2^{\text {nd }}$ of October, 2020 from https://eqe.ge/geo/static/827/ 
Ministry of Education, Science, Culture, and Sports of Georgia. (2019). Assessment Tool and Incentive Systems for Developing Higher Education Teachers' Performance. Retrieved on the $2^{\text {nd }}$ of November, 2020 from https://eqe.ge/ka/page/static/967/evropuliumaghlesi-ganatlebis-sivrcis-reformebis-mkhardatcheris-proeqti-profformance

National Center for Education Quality Development. (2018). World Federation of Medical Education (WFME). Retrieved on the $10^{\text {th }}$ of September, 2020 from https://eqe.ge/geo/static/643/

National Center for Education Quality Development. (2020). International Projects. Retrieved on the $7^{\text {th }}$ of September, 2020 from https://eqe.ge/geo/static/315/International-Projects

National Center for Education Quality Development. (2019). The National Center for Education Quality Development has become a member of the European Association for Quality Assurance in Higher Education (ENQA). Retrieved on the $10^{\text {th }}$ of September, 2020 from https://eqe.ge/ka/posts/2174/ganatlebis-khariskhis-ganvitarebiserovnuli-tsentri-umaghlesi-ganatlebis-khariskhis-uzrunvelqofis-evropuli-asotsiatsiisenqa-tsevri-gakhda

National Center for Educational Quality Enhancement. (2020). Association Agreement and Quality Assurance. Retrieved on the $7^{\text {th }}$ of September, 2020 from https://eqe.ge/geo/static/321/Association-Agreement

Shota Rustaveli National Science Foundation of Georgia. (2019). Georgia has officially become a member of the EU Intergovernmental Organization for Research and Innovation, EURAXESS. Retrieved on the $11^{\text {th }}$ of October, 2020 from https://rustaveli.org.ge/geo/siakhleebi/saqartvelo-evrokavshiris-kvlevebisa-dainovatsiebis-sakhelmtsifotashoriso-organizatsia-EURAXESS-is-tsevri-ofitsialuradgakhda

Tempus and Erasmus Mundus in Georgia. (2014). Tempus \& Erasmus Mundus in Georgia 1995-2013. Retrieved on the $10^{\text {th }}$ of October, 2020 from http://erasmusplus.org.ge/files/files/Tempus_and_Erasmus_Mundus_in_Georgiaoverview-ge.pdf 